\title{
CONSIDERATIONS REGARDING AN OUTBREAK OF MALARIA AT MORIB, FEDERATED MALAY STATES.
}

\author{
By C. STRICKLAND, M.A., B.C., \\ Travelling Medical Entomologist, Fed. Malay States. \\ (From the Malaria Bureau, Kuala Lumpor.)
}

MorIB being a seaside resort for the jaded European community of the State of Selangor, much consternation was caused when a succession of visitors there contracted fever. An investigation which I carried out at Morib leads me to publish this paper upon the epidemiology of the outbreak.

\section{The endemicity of fever at Morib.}

In the first place I ascertained that two of the cases among European visitors were first attacks. The infection may, however, have been acquired elsewhere and have previously remained latent. The other Europeans who were affected had all a previous history of fever and their illness may have been due to relapse brought about by cold or fatigue.

In the native population, however, the case rate pointed distinctly to the endemic origin of the fever. Moreover Mr Munro, late President of the Planters' Association of Malaya, who lives at Morib, informed me that fever has always been prevalent and that only the recent large influx of visitors has caused attention to be drawn to it.

The following notes will show the distribution of the cases, and the spleen index, among the local population in the vicinity of the Rest-house.

1. Government Rest-house. Of four Chinese servants two admitted that they had had fever while serving here; the head-boy who had been at the rest-house for four years had a greatly enlarged spleen. 
2. Malay servants living near the Rest-house. Among these there were two married couples each with one child. The men both complained of suffering constantly from fever, and one of them had a greatly enlarged spleen. Only one of the women complained of fever, and she had an enlarged spleen. Both children, who had been born here, had high fever and enlarged spleens when I saw them-one of them was highly anaemic and cachectic; blood examination revealed parasites of malignant tertian malaria in both children.

3. Chinese landed gentry behind the Rest-house. The Towkay confessed to an occasional bout of fever. His son denied having had fever, appeared in excellent health and had no palpable enlargement of the spleen. A little daughter was also reported never to have suffered, and she had no splenic enlargement. On the other hand the coolie of the house was always ill, and he had great enlargement of the spleen and looked miserable. The blood of these people was not examined.

4. Chinese shop-people of the village. The village lies about one hundred yards from the rest-house as the crow flies, and any day a half-dozen of the inhabitants in the houses could be found prostrate with fever. There were only two children who had been born here; one of these had a palpable spleen. An examination of the blood was made in six adult cases, and crescents were found in two.

5. Tamil estate coolies who lived in lines adjoining the village. The manager of the coconut estate on which the Tamils worked, informed me that they were always contracting fever, and that they then left the village to recover at a spot two or three miles inland. I palpated the spleens of eight of the coolies, and found five with definite enlargement.

6. European gentleman's compound 300 yards away from the village. The orang puteh ${ }^{1}$ himself suffered from a bad attack of fever when he first came here, while his servants are constantly down with it.

7. Malay kampong ${ }^{2}$ population. Three houses were visited. In two of them the occurrence of a little occasional fever among the children was admitted, but in five cases the spleen was not palpable. In the third house, under one hundred yards away, two children were down

1 White man, a term onìy applied to English here.

2 Small holding. 
with fever and all of four children examined had enlarged spleens. Crescents were found in two of these cases.

Enough has therefore been said to show that the whole population here is subject to fever, and the fact that the children of the stationary population suffer, and present signs of chronic disease, proves almost conclusively that the fever is endemic in Morib.

Although some of the local residents attributed the fever to various causes it was clear to me that we were dealing with malaria. The physician who attended one of the patients informed me, moreover, that he had found malaria parasites in the blood, and that all the clinical symptoms were those of malaria.

\section{The anopheline mosquitoes at Morib.}

Having concluded that malaria was endemic at Morib, I proceeded to collect and study the mosquitoes which occurred in the locality, and captured five species: ludlowi, rossi, umbrosus, sinensis, and tesselatus.

We know that ludlowi (Christophers), umbrosus (Watson), and sinensis (Tsuzuki) have all been incriminated elsewhere as vectors of malaria, but it does not follow that they serve as vectors at Morib.

For instance $I$ have found ludlowi, in great numbers, at Pasir Permatang over the river from Kuala Selangor, to mention but one place in the Malay States, and yet the natives never have fever there, and none of the children had enlarged spleens. Moreover Brooke reports that although ludlowi is very common at Cebu in the Philippines, yet there is no fever among the inhabitants. Similarly at Jeram, Selangor, a village very closely resembling Morib, except for the additional Malay fishing community at Jeram, I found large numbers of umbrosus in the fishermen's huts, although the spleen index of the Malay children (fifty examined) was practically nil. Again, in the case of sinensis, at Alor Pongsu in the state of Perak, the manager of an estate told me that at dusk anophelines came over like a flight of locusts, and I had the opportunity of seeing that, figuratively speaking, he was correct (I could easily have caught one hundred sinensis in five minutes if $I$ had wished); nevertheless the manager's family, and the children of the two hundred Javanese coolies who lived a few yards away, never suffered from fever.

Enough has therefore been said to show that although three reputed malaria vectors were present at Morib, we should not be $\dot{a}$ priori justified in saying that any one of them conveyed malaria in that locality. 
The relative prevalence of the different anopheline species is indicated by the numbers of each captured at Morib within a space of nine days:

\begin{tabular}{|c|c|c|c|c|c|c|}
\hline (1) & Iudlowi & .. & 236 & of which & 90 & were \\
\hline (2) & umbrosus & & 39 & " & 38 & ," \\
\hline (3) & rossi & & 36 & " & 15 & , \\
\hline (4) & sinensis & . & 1 & , & I & \\
\hline 5) & tesselatus & & 1 & " & 1 & , \\
\hline
\end{tabular}

What we know of the relative infectivity of these species in other places, is as follows:

(1) ludlowi: Christophers, in the Andamans, found 2/53 of this species infected; it is thought that the parasites which de Vogel found in a rossi-like mosquito were really found in ludlowi. Horne in India has also reported finding ludlowi infected.

(2) umbrosus: Watson has found this species infected, but he does not state what proportion were infected; it is reported that it has also been found infected in Borneo. Stanton found that of eleven specimens which had been exposed to infection not one was parasitised. I had previously examined about six of these mosquitoes with negative results.

(3) rossi: Eysell contends that several observers have found this species infected, but it seems doubtful whether the species has not been confused with ludlowi. Stanton dissected 136 specimens but found none parasitised.

(4) sinensis : this species certainly becomes parasitised (Tsuzuki, Kinoshita). Stanton found zygotes in two out of ninety-eight specimens which had been exposed to infection.

(5) tesselatus: nothing is known regarding the behaviour of malaria parasites in this species.

To these data may be added the result of my dissections at Morib as follows:

\begin{tabular}{|c|c|c|c|}
\hline & & No. examined & No. found infected \\
\hline ludlowi... & $\cdots$ & . 80 & 0 \\
\hline umbrosus & .. & 38 & 0 \\
\hline rossi $\quad \ldots$ & $\cdots$ & 13 & 0 \\
\hline sinensis & $\cdots$ & $\cdots$ & $\mathbf{0}$ \\
\hline tesselatus & .. & . & 0 \\
\hline
\end{tabular}

Conclusions on relative infectivity drawn from these figures would certainly be fallacious. It is very probable that rossi, if infective, is 
only infective to a much less degree than the others. Although about 2 per cent. of sinensis have been found to be infected in Malaya, the presence of this mosquito in great numbers in certain districts without causing malaria is in marked contrast to what we read of the amount of sickness caused by umbrosus and ludlowi: it is therefore probably less infective than these two species. We have only a little indirect evidence that umbrosus is probably less infective than ludlowi, viz.: at Jeram where there was no malaria, we caught large numbers of umbrosus in a few minutes, yet at Morib only thirty-eight were captured in nine days. The conditions, as said before, were almost identical. It is probable that at Morib very little of the fever was being caused by umbrosus and most of it by ludlowi.

At Morib it would seem that rossi and sinensis are both negligible factors in the situation; and this view is borne out by observations in other localities mentioned above, where, in spite of great numbers of these species, there was no fever. The conclusion we came to was that ludlowi was the greater cause of trouble, not only because of its probably greater infectivity, but also because of its greater numbers than umbrosus.

These conclusions by their necessary lack of precision show us how useful it would be if we had an accurate table of the relative infectivity of the different species, for we might then by merely counting the relative numbers of the prevalent species in any place find out exactly their relative culpability, and act accordingly.

With regard to preventive measures it would seem that greater success might be anticipated from a campaign against a mosquito, which was causing trouble more by reason of its large numbers than its high infectivity, than against a mosquito which was of high infectivity and low prevalence, for it is obvious that a larger proportion of the former type would be found and destroyed. This hypothesis might account for the great success which has attended Watson's antimosquito measures in the Federated Malay States in places like Port Swettenham, and for the comparative lack of results in the hill-country, for in a place like the former, ludlowi, the chief cause, as we think, of the fever, is a mosquito of relatively low infectivity, but of usually great prevalence. It breeds in enormous quantities, this being probably due to the larval characteristic, as in rossi, of disappearing on the slightest approach of danger. On the hill-land, on the other hand, maculatus and albirostris are never to be found in such great numbers, but they possess great infective powers. It follows that if malaria is easily allayed by anti- 
mosquito measures in any community, none of the local anophelines are highly infective.

At Morib therefore, the prospects would seem excellent of greatly reducing the disease by anti-ludlowi measures.

\section{SUMmaRY.}

Consideration of the outbreak of fever at Morib in Selangor, Federated Malay States, impresses us with the great practical importance of obtaining an exact comparative infectivity table of the various anophelines, compiled on a comprehensive basis; it is only by accurate study of a disease and the factors responsible for it, that it can be successfully combated.

At Morib we can only rely on general considerations and conclude that the species ludlowi has been causing most of the trouble.

It would seem that the reason that hill-land malaria in Malaya, and perhaps India, is so difficult to get rid of is because it is conveyed by mosquitoes of high infectivity and low prevalence, whereas low-land malaria can be easily allayed because it is conveyed by mosquitoes of low infectivity and high prevalence. It is a corollary to this that if malaria in any community can be easily allayed, it is caused by mosquitoes which possess low infectivity.

\section{REFERENCES.}

Brooke (1914). Concerning the freedom of Cebu from Malarial Fever. Military Surgeon, Xxxiv, 201.

Stanton (vII. 1914) in Report of Principal Medical Officer, Federated Malay States, for 1913. F.M.S. Govt. Gazette.

DE Vogel (1909). Myzomyia rossi als Überbrengster der Malaria. Genees. Tydschr. v. Ned. Ind. XIIX, 585.

Watson. The Prevention of Malaria in the Federated Malay States, in The Prevention of Malaria, by R. Ross, p. 554. London: John Murray. 